\title{
LASTEN JA VANHUSTEN TOIMIJUUS: DISKURSSIANALYYSI NELJÄN PUOLUEEN EDUSKUNTAVAALIOHJELMISTA
}

\author{
Anne-Maria Karjalainen: YTM, tobtoriopiskelija, Helsingin yliopisto \\ Tuulikki Ukkonen-Mikkola: KT, yliopistonlehtori, Jvuäskylän yliopisto \\ Milla Luodonpää-Manni: FT, yliopistonlebtori, Helsingin yliopisto \\ Ilkka Pietilä: YTM, FT, apulaisprofessori, Helsingin yliopisto \\ annemaria.karjalainen@gmail.com; tuulikki.t.ukkonen-mikkola@jju.fi; \\ milla.luodonpaa-manni@belsinki.fi; ilk.ka.pietila@helsinki.fi
}

Janus vol. 29 (1) 2021, 4-20

\section{Tiivistelmä}

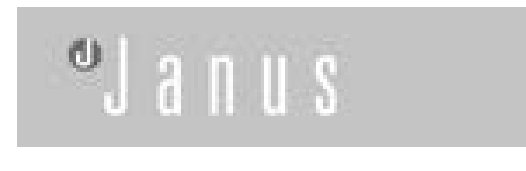

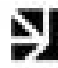

Tutkimuksessa tarkasteltiin, miten lapsia ja vanhuksia kuvataan toimijuuden näkökulmasta neljän suurimman puolueen eduskuntavaaliohjelmissa. Tutkimusmenetelmänä hyödynnettiin kriittistä diskurssianalyysï̈. Aineistosta oli tunnistettavissa kaksi toimijuuden diskurssia: passiivisen ja aktiivisen toimijuuden diskurssit, joissa molemmissa puhutaan lasten ja vanhusten toimijuudesta erityisesti palvelujärjestelmän kautta. Passiivisen toimijuuden diskurssissa erilaiset yhteiskunnalliset toimijat näyttäytyivät aktiivisina toimijoina lasten ja vanhusten sijaan. Aktiivisen toimijuuden puhe kietoutui palvelujärjestelmään, joka kuvautui keskeiseksi toimijuutta tuottavaksi tekijäksi. Lisäksi lasten toimijuus rakentuu tulevaisuudessa, kun taas vanhusten toimijuus on jotakin, mitä heillä on vanhenemisestaan huolimatta vielä jäljellä. Neljä suurinta puoluetta puhuvat vaaliohjelmissaan lasten ja vanhusten toimijuudesta julkisen sektorin järjestämien palveluiden kautta yllättävänkin yhdenmukaisella tavalla.

\section{JOHDANTO}

Poliittisessa keskustelussa ollaan tällä hetkellä huolissaan sekä lapsista että vanhuksista: vuonna 2018 syntyvyyttä mittaava kokonaishedelmällisyysluku oli kaikkien aikojen matalin (Tilastokeskus 2019) ja samaan aikaan ikääntyneiden määrä nousee väestöennusteen mukaan tulevina vuosina ennätyskorkealle (Tilastokeskus 2018). Lapsiin ja perheisiin sekä vanhuksiin liittyvät kysymykset ovat siten puolueiden poliittisten linjausten kannalta olennaisia aiheita. Hyvinvointivaltion taustalla olevista toimijoista juuri suurimmat eduskuntapuolueet edustajineen ovat määrittämässä lapsiin ja vanhuksiin vaikuttavaa lainsäädäntöä, palvelujärjestelmää ja suosituksia.
Tässä tutkimuksessa tarkastelemme diskursiivisesta näkökulmasta sitä, miten puolueet kuvaavat eduskuntavaaliohjelmissaan lapsia ja vanhuksia, sillä puolueiden tulkinnat lapsista ja vanhuksista vaikuttavat niiden tekemiin lapsi- ja vanhuuspoliittisiin ratkaisuihin. Vaalit ovat yksi keskeinen areena, jossa lapsiin ja vanhuksiin liitettävistä tulkinnoista käydään diskursiivista kamppailua. Artikkelimme kytkeytyy viime vuosina vahvistuneeseen keskusteluun osallistavasta politiikasta, jonka myötä lapset ja vanhukset on alettu nähdä toimijoina, joilla pitäisi olla mahdollisuus vaikuttaa itseään koskevaan päätöksentekoon (ks. Alanen 2009, 22; Häikiö ym. 2011, 241; Turja \& Vuorisalo 2017, 45). 
Tutkimusaineistomme koostuu neljän suurimman puolueen (vuosien 2011, 2015 ja 2019 eduskuntavaalien mukaan) eduskuntavaaliohjelmista vuosina 1991-2019. Tarkasteltavina olevista puolueista kokoomus, SDP ja keskusta voidaan tulkita intressipuolueiksi, jotka ovat yleispuolueistuneet. Perussuomalaiset puolestaan mielletään uudeksi, populistiseksi puolueeksi, joka on syntynyt yhteiskunnallisten ja poliittisten muutosten seurauksena. (Koiranen ym. 2019.) Eduskuntavaaliohjelmat ovat perinteisiä poliittisia tekstejä ja osa puolueiden strategista viestintää. Puolueen uskottavuuden kannalta ne ovat välttämättömiä: tarkasteluajanjaksolla jokainen puolue on julkaissut kaikkina vaalivuosina kirjallisen eduskuntavaaliohjelman. ${ }^{1} \quad$ Eduskuntavaaliohjelmia on tutkittu vähemmän kuin hallitusohjelmia, työryhmien mietintöjä ja raportteja tai eduskuntakeskusteluja (mm. Kantola 2006; Kananen 2008; Saarinen ym. 2014; Pulkki ym. 2017).

Tutkimme eduskuntavaaliohjelmia diskurssianalyyttisesti, sosiaalisen konstruktionismin viitekehyksestä. Sosiaaliseen konstruktionismiin perustuva diskurssianalyysi nostaa esiin kielen roolin sosiaalisen todellisuuden rakentumisessa: merkitykset syntyvät diskursiivisen toiminnan tuloksena. Diskurssit eivät pelkästään kuvaa todellisuutta, vaan ne muodostuvat myös kuvaksi tavoiteltavasta todellisuudesta - diskurssien voima on niiden kyvyssä ohjata poliittista päätöksentekoa (Sotkasiira 2018, 18). Diskurssilla eli puhetavalla tarkoitamme tässä vakiintunutta ja yhteisöllisesti tunnistettavaa merkityksellistämisen tapaa, joka voi muokata ymmärrystä sosiaalisesta todellisuudesta (Pietikäinen \&
Mäntynen 2009, 50-51; ks. myös Foucault 2005 [1969]).

Tutkimuksen aineisto on valittu vuosilta 1991-2019, koska 1990-luvun alun taloudellinen lama sekä muutokset kansainvälisessä politiikassa (Neuvostoliiton romahdus ja Euroopan unionin laajenemisen mahdollisuus) olivat ravistelevia murroksia suomalaisessa taloudellisessa ja poliittisessa toimintaympäristössä. Julkusen $(2017,10)$ mukaan 1990-luku oli Suomelle dramaattinen ja suuntaa muuttanut vuosikymmen. Muutoksia voidaan pitää tutkimuksellisesti mielenkiintoisena, uuden poliittisen aikakauden alkuna.

Pohjoismaisen hyvinvointivaltiomallin mukaisesti hoivapolitiikka ja hyvinvointipalveluiden käyttö ovat vahvasti lasten ja vanhusten suhdetta hyvinvointiyhteiskuntaan määrittävä tekijä. Palveluita voidaan pitää prosessina, johon osallistuminen rakentaa demokratiaa ja yhteisöllisyyttä. (Matthies 2017, 152.) Lapsiin ja vanhuksiin kohdistuvan hoivapolitiikan nykyvaihetta voi kuvata julkisen ja yksityisesti tuotetun hoivan uudenlaisena yhteensovittamisena (Anttonen 2009). Tästä esimerkkinä voidaan mainita tilaajatuottaja -malli, palvelusetelimallit ja ylipäätään hoivasektorin avaaminen kilpailulle. Lisäksi 2000-luvulla omaisten ja läheisten rooli hoivassa näyttäisi korostuvan (Häikiö ym. 2011, 244; Kalliomaa-Puha 2017; Ahosola 2018). Samoin kansalaisten osallisuus on vahvistuva toimintamalli, ja siksi on alettu puhua jopa osallistumisyhteiskunnasta hyvinvointiyhteiskunnan sijaan (Knijn \& Hopman 2015; Matthies 2017, 150). 


\section{LAPSET JA VANHUKSET SUOMALAISESSA HYVINVOINTIVALTIOSSA}

Tarkastelemme tässä luvussa ajankohtaista keskustelua liittyen lasten ja vanhusten ${ }^{2}$ ikäryhmämäärittelyihin, yleisiin sopimuksiin sekä perheen ja hyvinvointipalveluiden merkitykseen heidän elämässään. Lisäksi tuomme esille lasten ja vanhusten osallisuuteen ja toimijuuteen liittyviä kysymyksiä osana laajempaa yksilön toimijuuteen liittyvää yhteiskunnallista keskustelua. Tämä tarkastelu taustoittaa yhteiskunnallista toimintaympäristöä, jota myöhemmin artikkelissamme tarkastelemme suhteessa siihen, miten puolueiden eduskuntavaaliohjelmissa kuvataan lapsia ja vanhuksia.

Tulkinnat lasten ja vanhusten elämästä ovat historiallisesti, sosiaalisesti ja kulttuurisesti muotoutuneita ja ne ovat suhteessa aikakauden yhteiskunnalliseen, poliittiseen ja taloudelliseen tilanteeseen (Alanen 2009; Jyrkämä 2001, 176-177). Lainsäädäntö ja sopimukset määrittelevät lasten ja vanhusten elämää: sekä YK:n Lapsen oikeuksien sopimuksessa (1989, ratifioitu Suomessa 1991) että YK:n ikääntymistä koskevissa periaatteissa korostetaan oikeutta muun muassa tasa-arvoon, suvaitsevaisuuteen, osallisuuteen, huolenpitoon, koulutukseen sekä turvalliseen elämään. Lasten oikeuksien toteutumista valvoo Suomessa lapsiasianvaltuutettu (Turja \& Vuorisalo 2017, 37). Vanhuusasiainvaltuutetun tehtävän perustaminen on kirjattu pääministeri Sanna Marinin hallituksen ohjelmaan (Hallitusohjelma 2019, 149).

Lapsuus ja vanhuus voidaan yleisesti määritellä suhteessa työikäisyyteen, sille käänteisinä. Tällöin määrittelyyn sisältyy myös oletuksia toisista elämänvaiheista. Lapsuus tulkitaan yleisesti ihmisen elämänkulussa aikana syntymästä murrosikään, vanhuus aikana eläkeiän alkamisesta kuolemaan. (James ym. 2001, 26; Gilleard \& Higgs 2010.) Sekä lapsuus että vanhuus ovat elämänvaiheina monitahoisia ja muuttuvia (Haarni 2010; Forma ym. 2018). Keskeisenä erona lapsuuden ja vanhuuden välillä pidetään usein lasten ja vanhusten muuttuvaa psyykkistä ja fyysistä kompetenssia. Lasten voidaan tulkita olevan kasvamassa kohti lisääntyvää itsenäisyyttä. Lapsuus mielletään yksilön kehityksen, kasvun ja yhteiskuntaelämään sopeutumisen ajaksi, joksikin tulemiseksi. (Nikander \& Zechner 2006, 516.) Lapsuuden aikana yksilön ajatellaan tarvitsevan suojelua, ja lasten haavoittuvuus pohjautuu sekä kokemusten puutteeseen että fyysiseen heikkouteen ja käsitteellisen kehityksen tasoon (Hill 2005). Ikääntyneiden päätöksenteko oman elämän suhteen sekä keskeiset kansalaisoikeudet säilyvät yksilön vanhetessa. Vanhuudessa yksilö siirtyy kuitenkin kohti fyysistä haurautta sekä eri tavoin ja yksilöllisesti muuttuvaa kompetenssia. (Nikander \& Zechner 2006, 516.)

1980-luvulta alkaen on vahvistunut lapsuuden ja vanhuuden tulkinta, jonka mukaan lapset ja vanhukset ovat osallistujia ja toimijoita yhteiskunnassa. Tämä voidaan liittää laajempaan yksilöiden toimijuutta korostavaan yhteiskunnalliseen keskusteluun. (Alanen 2009, 22; Häikiö ym. 2011,241; Turja \&Vuorisalo 2017,45 .) Puhuttaessa lasten ja vanhusten toimijuudesta heidät ymmärretään yhteisöjen täysivaltaisiksi jäseniksi sekä aktiivisiksi ja vastuullisiksi kansalaisiksi. Lapset ja vanhukset eivät ole passii- 
visia kohteita vaan subjekteja omassa elämässään. He antavat osansa yhteiskuntaelämään ja kumpikin elämänvaihe voidaan nähdä yhteiskunnallisena institutionalisoituneena rakenteena. Lapsuus ja vanhuus ovat sellaisenaan arvokkaita elämänvaiheita; lapset eivät ole vain sijoitus tulevaisuuteen tai vanhukset rasitus yhteiskunnalle. (Corsaro \& Molinari 2001, 180; Alanen 2009, 176; Häikiö ym. 2011; Jyrkämä 2001; Ukkonen-Mikkola 2011, 168-170).

Toimijuuteen liittyy osallisuus, tosin käsitteitä käytetään osin myös synonyymeinä. Leonardin (2016) sekä Turjan ja Vuorisalon (2017) mukaan toimijuus merkitsee mahdollisuutta vaikuttaa ja saada aikaan muutoksia ympäristössä, osallisuus puolestaan sisältyy toimijuuteen ja se toteutuu sosiaalisissa suhteissa. Osaltaan toimijuuteen ja osallisuuteen liittyvän keskustelun tavoitteena on vahvistaa yksilöiden autonomiaa, itsemääräämisoikeutta ja osallistumista sekä aktivoida vastaamaan omasta hyvinvoinnistaan (Hvinden \& Johanson 2007). Samaan aikaan osallisuuteen on alettu suhtautua myös kriittisesti: on tunnistettu riski, että osallisuudesta on tulossa uusi ihmisten hallinnan väline, mikäli vastuu hyvinvoinnista siirretään ihmiselle itselleen ja ihminen subjektivoidaan irti julkisten palveluiden tarpeesta (Matthies 2017, 157).

Lasten ja vanhusten elämään liittyvät keskeisesti sekä perhe että yhteiskunnalliset palvelut. Lapsista pitävät pääasiallisesti huolta heidän vanhempansa ja myös vanhuksille puoliso, lapset ja lapsenlapset muodostavat tärkeän tukiverkoston. 2000-luvulla perheet ja läheiset nähdäänkin merkittävänä resurssina vanhusten hoivassa (Häikiö ym. 2011,
244; Ahosola \& Henriksson 2012, 244; Ahosola 2018, 249). Perinteisen sukupolvivastuun periaatteen mukaan ajatellaan, että perheen sekä yhteiskunnan tehtävä on huolehtia vanhusten sukupolven hyvinvoinnista (Marin 2001; Eriksson 2010).

Lasten ja vanhusten elämää kehystävät erilaiset institutionaaliset palvelut, $\mathrm{ku}-$ ten varhaiskasvatus, koulu sekä erilaiset sosiaali- ja terveyspalvelut (Alanen \& Bardy 1990,13, 16; Alanen 2009, 12-14). Toimiva palvelujärjestelmä on suomalaisen hyvinvointivaltion ydin ja näiden palveluiden piirissä lapset, vanhukset ja yhteiskunta kohtaavat. Suomessa ja muissa Pohjoismaissa hyvinvointivaltion keskeinen toimintaperiaate on perinteisesti ollut universalismi, jonka perusoletuksena on yhdenvertaisuus ja hyvän elämän tavoittelemisen mahdollistaminen sekä kattavat ja julkisesti rahoitetut palvelut yhdenvertaisesti kaikille ikäryhmille (Anttonen \& Sipilä 2010; Häikiö 2010). Lasten ja vanhusten palvelujärjestelmissä ja palveluiden piiriin pääsemisessä on kuitenkin eroavaisuuksia. Lapsille ja lapsiperheille tarjotut palvelut ovat yleensä lapsen iästä riippuvaisia, subjektiivisia etuuksia (vanhempainraha, varhaiskasvatus), kun taas iäkkäiden palveluihin sijoittuminen määrittyy monimutkaisemmilla ja harkinnanvaraisilla tavoilla. Vanhusten palveluihin pääsemiseen voi liittyä omaisolettamia (ks. Kalliomaa-Puha 2017). Esimerkiksi palvelujärjestelmä voi olla niin monimutkainen, että heikkokuntoinen vanhus ei selvï yksin vaan tarvitsee apua hoivan etsimiseen. Viimeaikainen tutkimus esittääkin, että perhe ja omaiset kantavat suurta vastuuta vanhusten 
asioiden järjestämisestä ja avun koordinoinnista (Ahosola 2012, 248).

Palveluiden universaali periaate on muuttumassa ja käsityksiä sekä käytäntöjä hyvinvointivaltion palveluista määritellään uudella tavalla (Häikiö 2010). Yksilön ja yhteiskunnan vastuun suhde on muuttunut uuden tulkinnan myötä: palveluista huolehtivat nykyään myös enemmän yksilöt, lähiyhteisöt, yritykset ja kolmas sektori (Häikiö ym. 2011). Ensin puhe hyvinvointivaltiosta muuttui 1990-luvulla hyvinvointiyhteiskuntapuheeksi (esim. Kettunen 2003) ja 2000-luvulla puhe hyvinvoinnista on muuttunut kilpailukykydiskurssiksi, jolloin hyvinvointi liitetään talouskasvuun ja valtion kapasiteettiin kilpailla kansainvälisistä liikkuvista pääomista (Fougner 2006; Kantola 2006; Karjalainen ym. 2017). Etenkin (liike) taloudellisen ajattelun korostaminen ja markkinoistuminen ovat haastaneet universalismin.

Muuttuvista puhetavoista huolimatta valtaosa suomalaisista pitää edelleen hyvinvointivaltiota ja -yhteiskuntaa elintärkeänä (Karjalainen ym. 2017). Perustuslain mukaan kunnat ovat vastuussa palveluiden tarjoamisesta niitä tarvitseville, kuten lapsille ja vanhuksille. Vanhushoivapolitiikassa kuntien vastuuta määritellään nyt uudelleen siten, että kunnan tehtävänä on luoda sellaiset olosuhteet, joissa ikääntyvät ottavat itse vastuuta hyvinvoinnistaan - perheenjäsentensä, läheisten ja verkostojen avulla. Muutoksen tavoitteeksi määrittyvät tällöin yksityisten kansalaisten kykyjen tuloksellinen hyödyntäminen ja kehittäminen. (Häikiö ym. 2011.)

\section{TUTKIMUSKYSYMYS, AINEISTO} JA MENETELMÄ

Tässä artikkelissa analysoimme tapoja, joilla puolueet eduskuntavaaliohjelmissaan kuvaavat lapsia ja vanhuksia sekä näiden toimijuutta. Edelliseen katsaukseen tukeutuen asetamme seuraavan tutkimuskysymyksen: minkälaisia 1) passiivista toimenpiteiden kohteena olemisen tai 2) aktiivisen toimijuuden diskursseja eduskuntavaaliohjelmissa esiintyy suhteessa lapsiin ja vanhuksiin.

Olemme kiinnostuneita siitä, millaisiin diskursseihin puolueet tukeutuvat puhuessaan lapsista ja vanhuksista. Tarkastelemme lapsiin ja vanhuksiin liittyvissä tekstikatkelmissa kielellisiä jännitteitä, sitä minkälaisessa kontekstissa kieltä käytetään, ja analysoimme vaikutuksia, joita kielenkäytöllä mahdollisesti on. Kiinnitämme huomiomme puolueiden kielenkäytön reunaehtoihin sekä kielellisten ilmaisujen mahdolliseen normativisuuteen ja niiden seurauksiin (ks. Pynnönen 2013). Analysoimme sitä, miten lasten ja vanhusten toimijuuden merkitykset vaaliohjelmateksteissä tuotetaan.

Tutkimuksessa sovellamme kriittistä diskurssianalyysiä, joka pyrkii paljastamaan kielenkäytön ja vallankäytön suhteita, jotka saattavat arjen "itsestäänselvyyksinä” jäädä huomaamatta (Fairclough 1997, 75). Kielenkäytössä on aina mukana mahdollisuus sosiaaliseen hyväksyntään tai hylkäämiseen; se rakentaa todellisuutta, jossa jokin vaihtoehto näyttäytyy toista hyväksyttävämpänä (Fairclough 2010, 57). Kriittinen diskurssianalyysi antaa mahdollisuuden arvioida kuinka diskursiiviset käytännöt vahvistavat tai purkavat sosiaalista 
järjestystä, mukaan lukien valtasuhteita (Fairclough \& Fairclough 2012, 12, 78). Ymmärrämme diskurssin tekstuaalisena kokonaisuutena ja osana sosiokulttuurisia käytäntöjä, ja se rakentaa osaltaan sosiaalista todellisuutta (Siltaoja \& Vehkaperä 2011; Pynnönen 2015, 34).

Tutkimuksen aineisto koostuu (aakkosjärjestyksessä) Kansallinen Kokoomus r.p.:n (jäljempänä kokoomus), Perussuomalaiset r.p.:n (perussuomalaiset), Suomen Keskusta r.p.:n (keskusta) ja Suomen Sosialidemokraattinen Puolue r.p.:n (SDP) vuosien 1991-2019 eduskuntavaaliohjelmista. Aineistoksi on valittu neljän suurimman puolueen eduskuntavaaliohjelmat, sillä nämä edustavat eduskuntavaaleissa eniten kannatusta saaneita puolueita. Tekstit ovat yhteiskunnallisessa kokonaisuudessa ajatellen puolue-eliitin kirjoittamia: tekstejä pääsevät tuottamaan vain puolueiden sisäpiirissä vaikuttavat henkilöt, kuten puoluesihteerit ja muut puoluetoimiston työntekijät, puolueen kansanedustajat ja puheenjohtajat (ks. lisää eduskuntavaaliohjelmien kirjoitusprosessista Karjalainen ym. 2017).

On huomionarvoista, että tutkimamme kohderyhmät, lapset ja vanhukset, eivät ole voineet vaikuttaa itse tekstien syntyyn: vallalla ja pääsyllä eduskuntavaaliohjelmien laadintaan on yhteys (Pynnönen 2015, 39). Tämän vuoksi eduskuntavaaliohjelmat ovat diskurssianalyyttisesti antoisia tutkimusaineistoja; niissä representoidaan (nimetään ja kuvataan) lapsuutta ja vanhuutta (ks. Pietikäinen \& Mäntynen 2009, 17, 58, 53-54; Pynnönen 2015, 39).

Tutkimuksen aineistona olevien eduskuntavaaliohjelmien muoto ja sana- määrä vaihtelevat paljon vaalivuodesta toiseen. Yleisellä tasolla eduskuntavaaliohjelmissa käsitellään keskeisiä politiikan teon kysymyksiä kuten sosiaali- ja terveyspalvelujärjestelmä, turvallisuus, maahanmuutto, kansainväliset suhteet, tasa-arvo ja liikenne. Kokonaisuudessaan aineisto sisältää 151432 sanaa ja jakautuu eri puolueiden välillä seuraavasti: keskusta 44 412, kokoomus 21 067, perussuomalaiset 32879 ja SDP 53074 sanaa.

Lapsia ja vanhuksia kuvaavien tekstikatkelmien tunnistamiseksi luimme mainittujen puolueiden eduskuntavaaliohjelmat vuosilta 1991-2019 useampaan kertaan. Lapsiin liittyviä aihepiirejä käsitellään vaaliohjelmissa esimerkiksi vanhemmuutta, huoltajuutta ja perheitä koskevissa jaksoissa. Vanhuksista puhutaan puolestaan yleisimmin ikääntymistä ja eläkkeitä koskevissa jaksoissa. Poimimme nämä tekstikatkelmat omaksi tiedostokseen taulukko-ohjelmaan, jolloin pystyimme paikallistamaan aineistosta lapsiin ja vanhuksiin liittyviä puhetapoja. Yhteensä tunnistimme eduskuntavaaliohjelmista lapsiin ja vanhuksiin liittyviä mainintoja 245 tekstikatkelmassa, joista 161 katkelmaa liittyi lapsiin ja 84 vanhuksiin. Tekstikatkelmista 212 käsitteli palveluiden, toimenpiteiden tai suojelun kohteena olemista ja 31 aktiivista toimijuutta. Tuloslukuun valitsimme 12 tekstilainausta, jotka edustavat koko aineistosta analysoituja lapsiin ja vanhuksiin liittyviä toimijuuden diskursseja mahdollisimman monipuolisesti ja kattavasti. ${ }^{3}$

Vaikka emme olleet ensisijaisesti kiinnostuneita puolueiden välisistä eroista lasten ja vanhusten toimijuuden kuva- 
uksissa, analyysin edetessä kiinnitimme huomiota näiden kuvausten odottamattomaan yhdenmukaisuuteen. Tämän vuoksi teimme systemaattisen vertailun eri puolueiden kuvauksista, joissa kiinnitimme huomiota siihen, millaisin tavoin puolueet kuvaavat lasten ja vanhusten toimijuutta sekä tunnistimme kuvauksia yhdistäviä tekijöitä, jotka voisivat selittää yhdenmukaisuutta.

\section{LAPSIIN JA VANHUKSIIN LIITTYVÄT TOIMIJUUDEN DISKURSSIT EDUSKUNTAVAALIOHJELMISSA}

Kokonaisuutena arvioiden puolueiden eduskuntavaaliohjelmissa puhutaan lapsista ja vanhuksista ymmärrettävästi ja populaaristi. Tekstit liikkuvat pääosin yleisellä, abstraktilla tasolla, kuitenkin ajoittain teksteissä on havaittavissa hyvin konkreettisia esimerkkejä ja viittauksia (esim. viittaukset tarkkoihin euromääriin tai hissien tarpeeseen). Tilastoihin tai tutkimuksiin perustuvaa argumentaatiota esiintyy aineistossa melko vähän. Torkki $(2014,223)$ on osoittanut, että tarina ja tarinallisuus on moninkertaisesti vaikuttavampaa kielenkäyttöä poliittisessa kontekstissa kuin faktat ja teoria (ks. myös Klaus 1971).

Huomionarvoista on, että vaaliohjelmissa käytetään huomattavasti enemmän (hyvinvointi)yhteiskunnan kuin (hyvinvointi)valtion käsitettä. Tarkasteltavana olevissa tekstikatkelmissa hyvinvointivaltio esiintyy vain yhden kerran, valtio 26 kertaa. Sen sijaan hyvinvointiyhteiskunta esiintyy 5 kertaa ja yhteiskunta 66 kertaa. Julkunen (2001) huomauttaakin, että hyvinvointivaltion käsite näyttää olevan häviämässä suo- malaisesta arki- ja poliittisesta kielestä ja korvautumassa hyvinvointiyhteiskunnalla; Kettunen (2003) pitää tätä siirtymää 1990-luvun kiinnostavimpana pohjoismaisen poliittisen kielen muutoksena. Eräsaaren $(2000,37)$ mukaan aatteellisesti himmenevässä hyvinvointivaltiossa ollaan asteittain siirtymässä ei-koskaan-valmiiseen hyvinvointiyhteiskuntaan, mikä tekee sosiaalipolitiikasta aiempaa hallitsemattomampaa. Sosiaalipolitiikan kentällä voi nähdä valtion lisäksi muita toimijoita (kolmas sektori, yritykset, järjestöt), jotka toimivat omine rationaliteetteineen (Julkunen 2001).

Aineistosta oli tunnistettavissa kaksi kirjallisuuskatsauksen mukaista diskurssia. Ensimmäisessä diskurssissa, "passiividiskurssi", lapset ja vanhukset määritellään passiivisiksi palveluiden, toimenpiteiden ja suojelun kohteiksi. Palvelujärjestelmä on subjekti, toimija, joka pitää huolta lapsista ja vanhuksista. Toisessa diskurssissa, "toimijuusdiskurssi”, lapset ja vanhukset määritellään toimijoina, mutta toimijuus näyttäytyy ajallisesti rajattuna ja kytkeytyy palvelujärjestelmään. Tutkimuksissa (esim. Matthies 2017) on todettu, että pohjoismaissa palvelujärjestelmä on lasten ja vanhusten suhdetta hyvinvointiyhteiskuntaan määrittävä tekijä.

Kriittistä diskurssianalyysiä hyödyntämällä nämä kaksi yllä mainittua diskurssia olivat löydettävissä kaikkien neljän suurimman puolueen eduskuntavaaliohjelmista. Kuten edellä totesimme, puolueiden välillä ei ollut havaittavissa merkittäviä eroja suhteessa lasten ja vanhusten toimijuutta tai passiivisuutta koskeviin diskursseihin. Nähdäksemme yhdenmukaisuus liittyy ennen muuta 
siihen, että kaikkien puolueiden ohjelmissa lapsia ja vanhuksia lähestytään valtaosin palvelujärjestelmän näkökulmasta avun ja tukemisen kohteina, mikä tukee erityisesti passiividiskurssin tapaa määritellä näitä ryhmiä. Seuraavissa analyysiluvuissa tuomme esiin vaaliohjelmateksteissä esiintyvät kaksi diskurssia, joiden kuvaamiseksi esitämme aineistoesimerkkejä kaikkien neljän puolueen ohjelmista.

\section{LAPSET JA VANHUKSET PASSIIVISENA PALVELUIDEN, TOIMENPITEIDEN JA SUOJELUN KOHTEENA}

Kaikkien tarkasteltavana olleiden puolueiden eduskuntavaaliohjelmat puhuvat lapsista ja lapsiperheistä sosiaali- ja terveysalan palvelujärjestelmän, toimenpiteiden ja suojelun kautta. Tässä luvussa tarkastelemme ensin erikseen lapsia ja vanhuksia palveluiden kohteena ja sen jälkeen molempia ryhmiä suojelupuheen kautta.

Palvelujärjestelmän yhteydessä korostuvat tulonsiirrot, lainsäädäntö, palvelurakenne ja ylipäätään erilaiset julkisen sektorin vastuulla olevat, verovaroin rahoitetut palvelut.

(1) Vaikeuksien kohdatessa perhettä pitää auttaa kokonaisuutena, ajoissa ja joustavasti eikä viipaloida apua erikseen lapsille ja aikuisille (Keskusta 2019).

(2) Lapsilisä- ja sairausvakuutusjärjestelmää on kehitettävä (Kokoomus 1991).

(3) Riittävää syntyvyyttä on rohkaistava ja lapsiperheiden tukitoimia on parannettava tekemällä mm. lasten kotihoito todelliseksi vaihtoehdoksi ja huolehdittava erityisesti äitien eläketurvan karttumisesta kotihoidon ajalta (Perussuomalaiset 2003).

(4) Pienten koululaisten iltapäivätoimintaa on toteutettu. Perhevapaakustannuksia on tasattu ja lapsilisiin sekä kotihoidon tukeen on tehty korotukset. (SDP 2007.)

Esimerkeissä 1-4 puhutaan palveluista ja etuuksista, mutta melko määrittelemättömästi ja populaaristi (varsinkin esimerkki 1). Puolueet eivät määrittele etuuksia ja palveluita esimerkiksi subjektiivisiin ja muihin kuin subjektiivisiin oikeuksiin, tai puhu määrärahasidonnaisuudesta tai kunnan järjestämistä vapaaehtoisista palveluista (ks. Tuori 2005, 188-191). Kaiken kaikkiaan lasten ja osin myös lapsiperheiden toimijuus on passiivista, toimenpiteiden kohteena olemista.

Myös suhteessa vanhuksiin/vanhuuteen eduskuntavaaliohjelmista on luettavissa passiivisen toimijuuden diskurssi, jossa puhe vanhuksista on puhetta palveluiden ja toimenpiteiden kohteena olemisesta eli eläkkeistä, avohoidosta, kotipalvelusta, palvelutarpeista, hoivapalveluista ja niiden henkilöstöstä tai esimerkiksi tulonsiirroista.

(5) Sosiaaliturvajärjestelmien yhtenäistämistä on jatkettava ja niiden kattavuutta on parannettava. Myös vanhuuden turvaa on kehitettävä. Kotona tapahtuva hoito on monissa tapauksissa yhteiskunnan järjestämää hoitoa inhimillisempää ja kustannuksiltaan huomattavasti edullisempaa. (Kokoomus 1991.)

Kokoomus rinnastaa esimerkissä 5 kotona tapahtuvan hoidon laitoshoitoon (vaikka laitoshoitoa ei mainita tekstissä suoraan). Tulkinta on kiintoisa poliitti- 
sen puheen kannalta: laitoshoito, jonka kokoomus väittää olevan yhteiskunnan järjestämää, asetetaan vastakkaiseksi ja kuvataan huonompana kuin (jonkin nimeämättömän tahon tuottama) kotihoito. Esimerkissä toimijoiden osalta kuvaus on ristiriitainen: kokoomus tuskin tarkoittaa faktisesti yhteiskuntaa eli esimerkiksi järjestöjen järjestämää hoitoa (ks. Eräsaari 2000), vaan valtion järjestämää hoitoa. Tällainen puhetapa heijastellee pitkään vallinnutta kotona vanhenemisen ensisijaisuuden trendiä ja sitä esiintyy myös muilla tarkastelun kohteena olleilla puolueilla, esimerkiksi keskustan vaaliohjelmassa vuodelta 2011:

(6) Lisäpanostusta tarvitaan kuntouttavaan kotihoitoon, perhehoitoon ja erilaisiin $y$ hdessä asumisen ratkaisuihin, kuten senioritaloihin ja osuuskuntapohjaiseen asumiseen (Keskusta 2011).

Ikäihmisten laatusuositukset ovat vuodesta 2001 kannustaneet kotiin annettavien palveluiden määrälliseen $\mathrm{ja}$ sisällölliseen kehittämiseen sekä laitoshoidon vähentämiseen (Laatusuositus hyvän ikääntymisen turvaamiseksi ja palvelujen parantamiseksi 2017-2019, 7).

Sen lisäksi, että lapset ja vanhukset asetetaan vaaliohjelmissa palveluiden ja toimenpiteiden passiivisiksi kohteiksi, heitä määritellään suojelun ja turvallisuuden kautta.

(7) Suunnittelussa on huomioitava niin lasten, vammaisten kuin vanhusten tarpeet - turvallisista leikkipaikoista esteettömiin kulkuväyliin (Kokoomus 1999).
Esimerkin 7 kaltaisia ajatuksia aineistossa esitetään muun muassa hissien rakentamisesta (keskusta 2007), vanhusten asumisesta (SDP 2003) ja ylipäätään ollaan huolissaan lasten ja vanhusten turvattomuuden tunteesta (SDP 2007). Turvallisuuspuheessa on merkillepantavaa se, että tekstit rakentavat kuvaa todellisuudesta, jossa on olemassa heikkoja ihmisryhmiä, jotka tarvitsevat vahvempien suojelua. Tällöin luodaan samalla valtasuhteita sekä määritellään sitä, ketkä ovat kelvollisia toimimaan yhteiskunnassa subjekteina ja ketkä ovat toimijuuden kohteita, objekteja.

On ongelmallista, jos haavoittuvuus otetaan kyseenalaistamatta koko ryhmää koskevaksi käsitteeksi, sillä tällainen lähestymistapa ei tavoita lasten tai vanhusten muodostaman kategorian heterogeenisyyttä (ks. Haarni 2010; Forma ym. 2018). Sen sijaan määritellessään lapset ja vanhukset turvattomiksi turvallisuuspuhe kategorisoi heidät homogeeniseksi ryhmäksi (ks. Nikander \& Zechner 2006, 517). Samalla kun haavoittuvuuden korostaminen suojelee kohderyhmäänsä, se vaimentaa toimijuutta ja korostaa marginaalisuutta (Nikander \& Zechner 2006, 515). Matthies $(2017,158)$ on jopa esittänyt, että hyvinvointipalvelut voidaan tulkita heikommassa asemassa olevien ihmisten valtaistamisen esteenä, yhteiskunnan kontrollin välineenä.

Passiivisen toimijuuden diskurssi on tulkittavissa niin, että vaikka käsitys hyvinvointivaltiosta on ollut 1990-luvun lamasta lähtien murroksessa (ks. esim. Kettunen 2008; Helne 2016), niin puhe palveluista tai palvelujärjestelmästä ei ole kadonnut. Päinvastoin eduskuntavaaliohjelmissa lapset ja vanhukset 
nähdään yhteiskunnan palveluiden, toiminnan ja suojelun kohteina.

\section{LASTEN JA VANHUSTEN AKTIIVISEN TOIMIJUUDEN DISKURSSI}

Neljän suurimman puolueen eduskuntavaaliohjelmissa puhe toimijuudesta kietoutuu palvelujärjestelmään samalla tavoin kuin passiividiskurssissa. Palvelujärjestelmä tukee ja mahdollistaa lasten sekä vanhusten toimijuutta.

Lapsiin liittyvä aktiivisen toimijuuden diskurssi suuntaa tulevaisuuteen, mutta ei tuota lapsille aktiivisen toimijan roolia nykyhetkessä.

(8) Että koti, lapsen päivähoito, koulu, järjestöt ja harrastukset muodostavat toisiaan tukevan kokonaisuuden, jossa kaikkien osapuolten vastuunoton ja yhteistyön avulla tarve yhteiskunnan rahoittamiin erityisratkaisuihin lasten ja nuorten hyvinvoinnin turvaamiseksi vähenee (Keskusta 2007).

(9) Lapsemme elävät kansainvälistyvässä maailmassa. Tulevaisuus merkitsee kansainvälistymistä. Siinä menestyvät ne, joilla on sekä tahtoa että osaamista. Meidän on huolehdittava, että Suomella näitä riittää. (Kokoomus 1999.)

Esimerkissä 8 rinnastetaan koti, päivähoito, koulu, järjestöt ja harrastukset yhdeksi toimijakokonaisuudeksi, jota verrataan yhteiskuntaan sen sijaan, että luokiteltaisiin koti, järjestöt ja harrastukset yhdeksi kokonaisuudeksi (yhteiskunta) ja päivähoito sekä koulu yhdeksi kokonaisuudeksi (valtio/kunta). Vaaliohjelmapuheessa tähdätään siihen, että "tarve yhteiskunnan rahoittamiin erityisratkaisuihin lasten ja nuorten hyvinvoinnin turvaamiseksi vähenee" eli haetaan yhteiskunnallista taloudellista säästöä muiden kuin "yhteiskunnan" toimijuuden vahvistamisella. Esimerkissä 9 korostetaan menestystä tulevaisuudessa, tässä tapauksessa kansainvälistymisen kautta (ks. Fougner 2006; Kantola 2006). Keskustan ja kokoomuksen lisäksi myös SDP (2015) esittää ohjelmassaan samankaltaisia ajatuksia lasten toimijuudesta tulevaisuudessa. Lapset nähdään enemmän tulevina (becoming) kuin olevina (being), jolloin heidän toimijuuttaan vahvistetaan aikuisuutta silmällä pitäen (esim. Gretschel \& Kiilakoski 2012). Näin korostuu lasten hyvinvoinnin takaaminen investointina tulevaisuuteen (ks. Naudeau ym. 2011).

(10) Lapset tarvitsevat oman valtuutetun valvomaan heidän etuaan julkisessa päätöksenteossa ja muualla yhteiskunnassa (SDP 2003).

Esimerkki 10 lasten omasta valtuutetusta on kiinnostava, koska Suomeen perustettiin lapsiasiavaltuutetun tehtävä vuonna 2004. Kuitenkaan lapsia ei olla ottamassa suoraan mukaan päätöksentekoon, vaikka jo 1990-luvulla on ehdotettu, että lasten äänioikeutta heitä koskevissa asioissa voitaisiin huomattavasti laajentaa ja äänestysikärajaa laskea (Archard 1993, 47). Strandell (2005) tulkitsee kansalaisoikeuksien puuttumisen erääksi lasten rakenteellisen haavoittuvuuden syyksi.

Vaaliohjelmien tapa puhua vanhuksista on pääosin kapeaa ja vanhukset tulkitaan yhtenäiseksi, hoivapalveluja tarvitsevaksi ikäluokaksi. Ohjelmissa on kuitenkin tunnistettavissa myös vanhuksiin liittyvää aktiivisen toimijuuden puhetta 
ja heidät nähdään toimijoina sekä menneisyyden että jossain määrin nykyisyydenkin kautta. On merkillepantavaa, että nämä esimerkit liittyvät konteksteihin, joissa ikäihmisiä lähestytään jostakin muusta kuin palvelujärjestelmän näkökulmasta.

(11) Vanhempien sukupolvien elämänkokemusta ei ole mielekästä sysätä aktiivisen $y$ hteiskunnan ulkopuolelle, vaan heille on tarjottava tilaa omien voimavarojensa mukaan yhteisöjen elämässä (Keskusta 2003A).

(12) Tämäkö on kiitos siitä, että isovanhempamme ja vanhempamme ovat kovalla työllä ja pitkää päivää tehden luoneet Suomen teollisuuden hyvinvointimme turvaamiseksi (Perussuomalaiset 2011).

Vanhusten elämänkokemusta arvostetaan ja heidät ajatellaan yhteisöjen jäseniksi esimerkissä 11. Kuitenkin ilmaisu "heille on tarjottava tilaa" viittaa siihen, että jollakin taholla (mahdollisesti työikäisillä aikuisilla ja päättäjillä) on tämä tila hallussaan. Hoikkala (1993) onkin esittänyt, että keski-ikäiset aikuiset määrittelevät asioiden arvojärjestyksen ja tekevät lapsia ja vanhuksia koskevat päätökset ja sopimukset. Esimerkki 12 nostaa esille sukupolvisopimuksen, jota perussuomalaisten mielestä rikotaan: vanhusten ikäpolvi nähdään uhrautuneena ja työteliäänä ja nykysukupolvi kiittämättömänä (ks. Eriksson 2010). Sukupolvisopimukseen viitataan myös SDP:n (2007), keskustan (2007) sekä kokoomuksen (1999) vaaliohjelmissa.

Kokonaisuutena eduskuntavaaliohjelmissa on enemmän keskustelua vanhusten kuin lasten aktiivisesta toimijuudesta. Lapset ovat eduskuntavaaliohjelmien teksteissä poikkeuksetta toiminnan kohteita ja heidät kuvataan pääosin tulevina yhteiskunnan rakentajina ja veronmaksajina. Vaaliohjelmien teksteissä yhteiskunta hallitsee lasten toimijuutta nykyhetkessä, lasten toimijuus suhteessa yhteiskuntaan nähdään rakentuvan tulevaisuudessa. Vanhukset tulkitaan osittain toimijoiksi, joskin keskustelu on kapeaa ja korostaa vanhusten hoivapalveluiden tarvetta. Erityisesti vaaliohjelmissa korostuu arvostuspuhe suhteessa vanhusten menneisyydessä tapahtuneeseen toimijuuteen (työura- ja veteraanipuhe).

\section{LOPUKSI}

Tutkimuksessa tarkasteltiin, miten lapsia ja vanhuksia kuvataan toimijuuden näkökulmasta neljän suurimman puolueen eduskuntavaaliohjelmissa. Aineistosta oli tunnistettavissa kaksi toimijuuden diskurssia: passiivisen ja aktiivisen toimijuuden diskurssit, joissa molemmissa puhutaan lasten ja vanhusten toimijuudesta erityisesti palvelujärjestelmän kautta. Passiivisen toimijuuden diskurssissa erilaiset yhteiskunnalliset toimijat näyttäytyivät aktiivisina toimijoina lasten ja vanhusten sijaan. Lapset ja vanhukset kuvattiin pääasiassa palveluiden, toimenpiteiden ja suojelun kohteina ilman omaa itsenäistä toimijuutta. Lisäksi lapset ja vanhukset nähdään vaaliohjelmissa homogeenisinä ryhminä: heidät tulkitaan haavoittuviksi ja suojelua tarvitseviksi, jolloin heidän toimijuuttaan voidaan riisua ja korostaa suojelun tarvetta (ks. Nikander \& Zechner 2006, 515; Matthies 2017, 158). Palvelujärjestelmä-, toimenpideja suojelupuhe korostavat hyvinvointivaltion valtaa ja vastuuta suhteessa lapsiin ja vanhuksiin. 
Aktiivisen toimijuuden puhe kietoutui niin ikään palvelujärjestelmään, joka kuvautui keskeiseksi toimijuutta tuottavaksi tekijäksi. Lisäksi lasten toimijuus rakentuu tulevaisuudessa, kun taas vanhusten toimijuus on jotakin, mitä heillä on vanhenemisestaan huolimatta vielä jäljellä.Vanhusten toimijuus nähdään tärkeäksi niiden uhrausten vuoksi,joita he ovat tehneet työikäisinä Suomen hyväksi. Lasten oikeutus toimijuuteen (joskin rajoitettuun) syntyy heidän tulevaisuuden potentiaalistaan, mutta lasten toimijuus itseisarvona ei ole toimijuuspuheen keskiössä. Eduskuntavaaliohjelmissa tuotettu puhe ei osallistu ajankohtaiseen keskusteluun, jossa lapset ja vanhukset tulkitaan subjekteina, osallistujina ja toimijoina yhteiskunnassa (Corsaro \& Molinari 2001, 180; Alanen 2009, 176; Häikiö ym. 2011; Jyrkämä 2001; UkkonenMikkola 2011).

Puolueet käyttävät hyvin vähän valtion käsitettä puhuessaan lapsista ja vanhuksista, sen sijaan puolueet puhuvat (hyvinvointi)yhteiskunnasta. Näitä termejä ei määritellä ja niitä käytetään viittaamaan valtioon, kuntiin, kolmanteen sektoriin ja järjestöihin. Kuten Julkunen (2001) ja Kettunen (2003) toteavat, hyvinvointivaltion käsite on häviämässä julkisesta keskustelusta.

Tutkimuksemme mukaan neljä suurinta suomalaista puoluetta puhuvat eduskuntavaaliohjelmissaan lasten ja vanhusten toimijuudesta julkisen sektorin järjestämien palveluiden kautta yllättävänkin yhdenmukaisella tavalla. Aiemmissa tutkimuksissa eduskuntavaaliohjelmista puolueiden ideologioihin kytkeytyviä eroja on tunnistettu esimerkiksi suhteessa hyvinvointiin
(Karjalainen ym. 2017). On merkillepantavaa, ettei laajassa ja pitkän aikavälin kattavassa aineistossamme esiinny kuin harvoja poikkeuksia, joissa lapsia tai vanhuksia käsiteltäisiin jostakin muusta kuin palvelujärjestelmän näkökulmasta. Näin on erityisesti vanhusten kohdalla silloin, kun viitataan heidän elämänkokemukseensa tai arvostukseen menneiden saavutusten kautta. Näyttää siltä, että lapsia ja vanhuksia koskevissa linjauksissaan puolueet näkevät julkisen vallan ensisijaisena toimijana, tukeutuvat tämän vuoksi palvelu- ja etuusjärjestelmään haavoittuvien ryhmien aseman parantamisessa, eivätkä esitä lasten tai vanhusten asemaa koskevia laajempia visioita.

Diskurssianalyysissa tarkastellaan myös kielenkäytön seurauksia (esim. Pynnönen 2013): puolueiden käyttöönottamat diskurssit määrittävät niiden tekemää politiikkaa suhteessa lapsiin ja vanhuksiin. Käytännön sosiaalipolitiikan kannalta voidaan nähdä ongelmallisena, että puolueet näyttävät välttävän konkreettisten toimijoiden nimeämistä ohjelmissaan, ja vetoavat sen sijaan epämääräisesti "yhteiskuntaan". Puolueiden tahtotila lasten ja vanhusten hoivavastuusta verhoutuu määrittelemättömäksi valtio- ja yhteiskuntapuheen taakse. Jää epäselväksi, minkä tahojen puolueet haluaisivat lopulta olevan vastuussa lapsiin ja vanhuksiin kohdistuvien palveluiden ja turvallisuuden takaamisesta. Paikallistamamme toimijuuden diskurssit osoittavat, että ainakaan se ei ole lapset tai vanhukset itse: vaaliohjelmissa lapset ja vanhukset ikään kuin asetetaan julkisesti rahoitettujen palveluiden muodostaman turvaverkon päälle ja oletetaan, että "yhteiskunta" pitää heistä huolen. 
Tuloksista voidaan tulkita oletus, että perhe ja muut lähisuhteet katoavat erityisesti vanhusten ympäriltä. Tällä puolueiden tekemällä diskursiivisella valinnalla on seurauksensa: vaaliohjelmissa ylläpidetään ikään kuin normatiivisena totuutena pohjoismaista, universaalia palvelujärjestelmää ja samaan aikaan palveluiden universaalius on murtumassa ja palvelujärjestelmää määritellään uudestaan (Häikiö 2010). Tutkimusten mukaan suomalainen sosiaalipolitiikka on muuttunut yksilön aktiivista vastuunottoa korostavaksi (Julkunen 2001; Kananen 2008), mutta tämä ei resonoi eduskuntavaaliohjelmiin. Vaaliohjelmissa ei myöskään oteta kantaa palveluiden markkinoistumiseen, kilpailutukseen tai yksityistämiseen. Näyttäisikin siltä, että eduskuntavaalien alla puolueet lähestyvät äänestäjiä vaaliohjelmilla, jotka ovat melko irrallaan hallitusohjelmista, päätöksenteosta ja tapahtuneista lainmuutoksista.

Se, että aineisto koostui vain neljän puolueen vaaliohjelmista, rajoittaa tulosten yleistettävyyttä. Näin ollen esimerkiksi vasemmistoliiton ja vihreiden ohjelmat jäivät tarkastelun ulkopuolelle, vaikka nämä puolueet ovat olleet hallitusvastuussa tarkasteluajanjaksolla. Jatkossa olisi hedelmällistä tutkia eduskuntavaaliohjelmien suhdetta vaalien jälkeen muodostettaviin hallitusohjelmiin sekä toteutettavaan politiikkaan (esimerkiksi vaalikaudella syntyvä lainsäädäntö).

\section{VIITTEET}

1 Perussuomalaiset rp. perustettiin vuoden 1995 toukokuussa ja puolue osallistui ensimmäistä kertaa eduskuntavaaleihin vuon- na 1999. Näin ollen perussuomalaisten osalta aineisto kattaa puolueen eduskuntavaaliohjelmat vuosilta 1999-2019.

2 Käytämme artikkelissa termejä vanhus ja vanhuus, koska viranomaisviestinnässä käytetään laajalti esim. vanhuspalvelujen käsitettä. Lisäksi puolueet käyttävät eduskuntavaaliohjelmissaan pääsääntöisesti tätä käsitettä.

3 Aineistolähteissä on lueteltu koko tutkimusaineisto. Luettelossa on merkitty tähdellä ne eduskuntavaaliohjelmat, joista on valittu aineistoesimerkkejä tähän artikkeliin.

\section{Tutkimusaineisto}

Keskusta 1991. Keskustan vaalijulistus.

Keskusta 1995. Puolueen keskeisimmät vaaliteemat: Yrittäjyys, työllisyys ja oikeudenmukainen hyvinvointi.

Keskusta 1999. Omistamisella on väliä.

^Keskusta 2003A. Suomen Keskusta. Vaaliohjelma - Koko Suomen voimavarat käyttöön - Keskustan vaaliohjelma -

Keskusta 2003B. Kannanotto. Puoluevaltuuskunta 24.11.2002 Vantaalla. Keskusta eduskuntavaaleissa 2003: Valoisampi vaihtoehto.

^Keskusta 2007. Suomen Keskusta. Vähän kuin itseäsi äänestäisit. Keskustan tavoitteet vaalikaudelle 2007-2011.

^Keskusta 2011. Suomen Keskusta. Vaaliohjelma vuoden 2011 eduskuntavaaleihin.

Keskusta 2015. Suomen Keskusta r.p. Eduskuntavaalit 2015.

^Keskusta 2019. Keskustan vaaliohjelma. Eduskuntavaalit 2019.

^Kokoomus 1991. Eduskuntavaalit 1991. Kokoomuksen vaalitavoitteet.

Kokoomus 1995. KANSALLINEN KOKOOMUS. Järvenpää 28.1.1995. Vaalikampanjan avaus - vaalitavoitteita.

^Kokoomus 1999. Puoluehallitus 7.4.1998. Vaalilupaus.

Kokoomus 2003. TAVOITTEENA PAREMPI ARKI - KOKOOMUKSEN KUUDEN KOHDAN OHJELMA.

Kokoomus 2007. Vastuullinen markkinatalous ja sen vaikutukset suomen tulevaisuuteen. 
Kokoomus 2011. Matkaopas hyvinvointivaltiosta paremminvointivaltioon. Kokoomuksen eduskuntavaaliohjelma 2011.

Kokoomus 2015. Jos vanha tapa ei toimi, tarvitaan KORJAUSLIIKE.

Kokoomus 2019. Kokoomuksen eduskuntavaaliohjelma 2019: Luotamme Suomeen.

Perussuomalaiset 1999. Perussuomalaisten eduskuntavaaliohjelma 1999. Oikeutta ja turvallisuutta Suomen kansalle.

*Perussuomalaiset 2003. Perussuomalaisten Eduskuntavaaliohjelma 2003.

Perussuomalaiset 2007. Perussuomalaiset rp. Eduskuntavaaliohjelma 2007. Oikeudenmukaisuuden, hyvinvoinnin ja kansanvallan puolesta!

*Perussuomalaiset 2011. Suomalaiselle sopivin. Perussuomalaiset r.p:n eduskuntavaaliohjelma 2011.

Perussuomalaiset 2015. Perussuomalaisten eduskuntavaaliohjelma.

Perussuomalaiset 2019. Äänestä Suomi takaisin.

SDP 1991. Sinulle, suomelle, euroopalle. Sdp, tavoitteita vaalikaudelle 1991-1994.

SDP 1995. Uuden vastuun aika.

SDP 1999. Eduskuntavaalit 1999. Tavoitteena täystyöllisyys. Vaalijulistus.

*SDP 2003. SDP:n vaaliohjelma 2003.Varma vaihtoehto - työllä turvaamme hyvinvointiyhteiskunnan.

*SDP 2007. Vaaliohjelma. Reilu Suomi työtä ja välittämistä.

SDP 2011. Työn ja oikeudenmukaisuuden puolesta

SDP 2015. Suunta Suomelle. Työtä, tasa-arvoa ja turvallisuutta. SDP:n vaaliohjelma.

SDP 2019. Tulevaisuuslinja. Sdp:n vaalitavoitteita. Ja muutoksen suunta 2030.

\section{KirjallisuUs}

Ahosola, Päivi (2018) Vanhushoivapolitiikan uusfamilismi. Omaisettomat hoivan tarvitsijat institutionaalisen hallinnan kohteena. Acta Universitatis Tamperensis 2401. Tampere: Tampere University Press.

Ahosola, Päivi \& Henriksson, Lea (2012) Perhe ja läheiset kuntien vanhuspoliit- tisissa asiakirjoissa. Yhteiskuntapolitiikka 77 (3), 239-252.

Alanen, Leena \& Bardy, Marjatta (1990) Lapsuuden aika ja lasten paikka. Tutkimus lapsuudesta yhteiskunnallisena ilmiönä. Julkaisuja 12. Helsinki: Valtion painatuskeskus.

Alanen, Leena (2009) Johdatus lapsuudentutkimukseen. Teoksessa Leena Alanen \& Kirsti Karila (toim.) Lapsuus, lapsuuden instituutiot ja lasten toiminta. Tampere: Vastapaino, 9-30.

Anttonen, Anneli (2009) Hoivan yhteiskunnallistuminen ja politisoituminen. Teoksessa Anneli Anttonen, Heli Valokivi \& Minna Zechner (toim.) Hoiva - tutkimus, politiikka ja arki. Tampere:Vastapaino, 54-98.

Anttonen, Anneli \& Sipilä, Jorma (2010) Universalismi Britannian ja Pohjoismaiden sosiaalipolitiikassa. Janus 18 (2), 104-120.

Archard, Richard (1993) Children: Rights and Childhood. London: Routledge.

Corsaro, William Arnold \& Molinari, Luisa (2001) Entering and observing in children's worlds: A reflection on a longitudinal ethnography of early education in Italy. Teoksessa Pia Chirstensen \& Allison James (toim.) Perspectives and practices. London: Falmer Press, 179-200.

Eriksson, Ilse (2010) Sukupolvivastuu ja syyllisyys: diskursseja aikuisten lasten huolenpidosta vanhemmistaan. Aikuiskasvatus 30 (1), 4-13. https://doi. org/10.33336/aik.93854

Eräsaari, Risto (2000) Sosiaalipolitiikan viitekehys: aika, yhteiskunta, yhteisö, maailma. Teoksessa Eija Nurminen (toim.) Sosiaalipolitiikan lukemisto. Helsinki: Palmenia.

Fairclough, Norman (1997) Miten media puhuu. Tampere:Vastapaino.

Fairclough, Norman (2010) Critical discourse analysis. The critical study of language. New York: Routledge.

Fairclough, Isabela \& Fairclough, Norman (2012) Political discourse analysis. A method for advanced students. London: Routledge. https://doi. org/10.4324/9780203137888

Forma, Leena \& Rissanen, Pekka \& Aaltonen, Mari \& Pulkki, Jutta \& Raitanen, Jani \& Jylhä, Marja (2018) Vanhuusiän 
ympärivuorokautinen pitkäaikaishoito keskittyy yhä selvemmin viimeisiin elinvuosiin.Vuosien 2001-2003 ja 20092011 vertailu. Yhteiskuntapolitiikka 83 (4), 399-411.

Foucault, Michel (2005 [1969]) Tiedon arkeologia. Suom. Tapani Kilpeläinen. Tampere:Vastapaino.

Fougner, Tore (2006) The state, international competitiveness and neoliberal globalisation: is there a future beyond the competition state? Review of International Studies 32 (1), 165-185. https:// doi.org/10.1017/S0260210506006978

Gilleard, Chris \& Higgs, Philip (2010) Aging without agency: Theorizing the fourth age. Aging \& Mental Health 14 (2), 121-128. https://doi. org/10.1080/13607860903228762

Gretschel, Anu \& Kiilakoski, Tomi (2012) Demokratiaoppitunti. Lasten ja nuorten kunta 2000-luvun alussa. Nuorisotutkimusseuran julkaisuja 118. Helsinki: Nuorisotutkimusverkosto.

Haarni, Ilkka (2010) Kolmas elämä. Helsinki: Gaudeamus.

Hallitusohjelma 2019. Pääministeri Sanna Marinin hallituksen ohjelma 10.12.2019. Osallistava ja osaava Suomi - sosiaalisesti, taloudellisesti ja ekologisesti kestävä yhteiskunta. Valtioneuvoston julkaisuja 2019:31. Helsinki:Valtioneuvosto.

Helne, Tuula (2016) Vakuutus kasvugeneraattorina: Päästötöntä edistystä? Janus 24 (2), 156-171. https://doi. org/10.31522/p.24.2(52).2

Hill, Malcolm (2005) Ethical considerations in researching children's experiences. Teoksessa Sheila Green \& Diane Hogan (toim.) Researching children's experience. Approaches and methods. London: Sage, 61-86.

Hoikkala, Tommi (1993) Katoaako kasvatus, himmeneekö aikuisuus? Aikuistumisen puhe ja kulttuurimalli. Helsinki: Gaudeamus.

Hvinden, Bjorn \& Johansson, Håkan (2007) Citizenship in nordic welfare states: Dynamics of choice, duties and participation in a changing Europe. London: Routledge.

Häikiö, Liisa (2010) The Diversity of citizenship and democracy in local public management reform. Public Manage- ment Review 12 (3), 363-384.

Häikiö, Liisa \& van Aerschot, Lina \& Anttonen, Anneli (2011) Vastuullinen ja valitseva kansalainen: vanhushoivapolitiikan uusi suunta. Yhteiskuntapolitiikka 76 (3), 239-250.

James, Allison \& Jenks, Cris \& Prout, Alan (2001) Theorizing Childhood. Cambridge: Polity Press.

Jokinen, Arja \& Juhila, Kirsi \& Suoninen, Eero (2016) Diskursiivinen maailma. Teoreettiset lähtökohdat ja analyyttiset käsitteet. Teoksessa Arja Jokinen, Kirsi Juhila \& Eero Suominen (toim.) Diskurssianalyysi. Teoriat, peruskäsitteet ja käyttö. Tampere:Vastapaino, 25-50.

Julkunen, Raija (2001) Hyvinvointiyhteiskunta - mikä se on ja mihin se kannustaa. Kansantaloudellinen aikakausikirja 97 (2), 200-205.

Julkunen, Raija (2017) Muuttuvat hyvinvointivaltiot. Eurooppalaiset hyvinvointivaltiot reformoitavina. Jyväskylä: SoPhi.

Jyrkämä, Jyrki (2001) Vanheneminen ja vanhuus. Teoksessa Anne Sankari \& Jyrki Jyrkämä (toim.) Lapsuudesta vanhuuteen, iän sosiologia. Jyväskylä: Gummerus, 267-323.

Kalliomaa-Puha, Laura (2017) Vanhuksen oikeus hoivaan ja omaisolettama. Gerontologia 31 (3), 227-242. https://doi. org/10.23989/gerontologia.63421

Kananen, Johannes (2008) Kilpailukyky ja tuottavuus 2000-luvun sosiaalipolitiikassa.Yhteiskuntapolitiikka 73 (3), 239-249.

Kantola, Anu (2006) Suomea trimmaamassa: suomalaisen kilpailuvaltion sanastot. Teoksessa Risto Heiskala \& Eeva Luhtakallio (toim.) Uusi jako. Helsinki: Gaudeamus, 156-178.

Karjalainen, Anne-Maria \& LuodonpääManni, Milla \& Laippala,Veronika (2017) Hyvinvointivaltio ja kielitietoisuus: $\mathrm{Hy}-$ vinvoinnin diskurssit neljän suurimman puolueen eduskuntavaaliohjelmissa. Teoksessa Sirkku Latomaa, Emilia Luukka \& Niina Lilja (toim.) Kielitietoisuus eriarvoistuvassa yhteiskunnassa. Suomen soveltavan kielitieteen yhdistyksen julkaisuja n:o 75. Jyväskylä: Suomen soveltavan kielitieteen yhdistys AFinLA.

Kettunen, Pauli (2003) Yhteiskunta. Teoksessa Matti Hyvärinen, Jussi Kurunmäki, Kari Palonen, Tuija Pulkkinen \& Henrik 
Stenius (toim.) Käsitteet liikkeessä. Tampere:Vastapaino, 167-212.

Kettunen, Pauli (2008) Globalisaatio ja kansallinen me. Kansallisen katseen historiallinen kritiikki. Tallinna:Vastapaino.

Klaus, Georg (1971) Politiikan kieli. Suom. Vesa Oittinen 1975. Helsinki: Gaudeamus.

Knijn, Trudie \& Hopman, Marit (2015) Parenting support in the Dutch participation society. Social Policy \& Society 14 (4), 645-656. https://doi.org/10.1017/ S1474746415000329

Koiranen, Ilkka \& Koivula, Aki \& Mickelsson, Rauli \& Saarinen, Arttu (2019) Kenen joukoissa seisot ja kenen puolesta toimit? SDP:n ja vihreiden puoluekokoukset edustavuuden näkökulmasta. Politiikka 61 (4), 308-336.

Laatusuositus hyvän ikääntymisen turvaamiseksi ja palvelujen parantamiseksi 2017-2019. Sosiaali- ja terveysministeriön julkaisuja 2017:6. Helsinki: Sosiaali- ja terveysministeriö.

Leonard, Madeleine (2016) The sociology of children, childhood and generation. London: Sage. https://doi. org/10.4135/9781529714494

Marin, Marja (2001) Tarkastelukulmia ikään ja ikääntymiseen. Teoksessa Anne Sankari \& Jyrki Jyrkämä (toim.) Lapsuudesta vanhuuteen, iän sosiologia. Jyväskylä: Gummerus, 17-45.

Matthies, Aila-Leena (2017) Osallistumisen lupaus ja petos hyvinvointipalveluissa. Sosiologia 54 (1), 149-165.

Naudeau, Sophie \& Kataoka, Naoko \& Valerio, Alexandria \& Neuman, Michelle \& Kennedy Elder, Leslie (2011) Investing in young children. An early childhood development guide for policy dialogue and project preparation. World Bank. https:// doi.org/10.1037/e596922012-001

Nikander, Pirjo \& Zechner, Minna (2006) Ikäetiikka - elämänkulun ääripäät, haavoittuvuus ja eettiset kysymykset. Yhteiskuntapolitiikka 71 (5), 515-526.

Pietikäinen, Sari \& Mäntynen, Anne (2009) Kurssi kohti diskurssia.Tampere:Vastapaino. Pulkki, Jutta \& Tynkkynen, Liina-Kaisa \& Jolanki, Outi (2017) Aktivoivat, muuttuvat ja sopimattomat vanhenemisen paikat. Analyysi vanhuspalvelulain lähetekeskustelusta. Yhteiskuntapolitiikka 82 (1), 45-54.
Pynnönen, Anu (2013) Diskurssianalyysi: tapa tutkia, tulkita ja olla kriittinen. N:o 379/2013 working paper. Jyväskylän yliopiston kauppakorkeakoulu.

Pynnönen, Anu (2015) Varjosta valokeilaan. Kriittisiä diskurssianalyysejä huonosta johtamisesta. Jyväskylä: Jyväskylä University Printing House.

Rotkirch, Anna \& Miettinen, Anneli (2016) Childlessness in Finland. Teoksessa Michaela Kreyenfeld \& Dirk Konietzka (toim.) Childlessness in Europe: contexts, causes, and consequences. Rostock, Germany: Max Planck Institute for Demographic Research. https://doi.org/10.1007/9783-319-44667-7 7

Saarinen, Arttu \& Salmenniemi, Suvi \& Keränen, Harri (2014) Hyvinvointivaltiosta hyvinvoivaan valtioon. Hyvinvointi ja kansalaisuus suomalaisessa poliittisessa diskurssissa.Yhteiskuntapolitiikka 79 (6), 605-618

Siltaoja, Marjo \& Vehkaperä, Meri (2011) Diskurssianalyysi johtamis- ja organisaatiotutkimuksessa. Teoksessa Anu Puusa \& Pauli Juuti (toim.) Menetelmäviidakon raivaajat, Perusteita laadullisen tutkimuslähestymistavan valintaan. Jyväskylä: Hansaprint, 206-231.

Sotkasiira, Tiina (2018) Lähtemisen pakot ja mahdollisuudet syrjäseuduilla. Pakolaistaustaisten nuorten asuinpaikkavalinnat viranomaispuheen kohteena. Nuorisotutkimus 36 (3), 5-22.

Strandell, Harriet (2005) Lapset, etiikka ja vaikea osallisuus. Laadullisen sosiaalitutkimuksen eettiset kysymykset. Työpapereita 1/2005. Helsinki: Stakes, 31-38.

Tilastokeskus (2018) Suomen virallinen tilasto (SVT): Väestöennuste [verkkojulkaisu]. ISSN=1798-5137. 2018, Liitetaulukko 1. Väestö ikäryhmittäin koko maa 1900-2070 (vuodet 2020-2070: ennuste). Helsinki:Tilastokeskus [viitattu: 21.11.2018]. Saantitapa: http://www.stat.fi/til/vaenn/2018/vaenn_2018_2018-11-16_tau_001_fi.html

Tilastokeskus (2019) Suomen virallinen tilasto (SVT): Syntyneet [verkkojulkaisu]. ISSN=1798-2391. 2018. Helsinki: Tilastokeskus [viitattu: 19.12.2019]. Saantitapa: http://www.stat.fi/til/ synt/2018/synt_2018_2019-04-26_ tie 001_fi.html

Torkki, Juhana (2014) Tarinan valta. Kertomus luolamiehen paluusta. Keuruu: Otava. 
Turja, Leena \& Vuorisalo, Mari (2017) Lasten oikeudet, toimijuus ja osallisuus oppimisessa. Teoksessa Merja Koivula, Anna Siippainen \& Paula Eerola-Pennanen (toim.) Valloittava varhaiskasvatus. Oppimista, osallisuutta ja hyvinvointia. Tampere: Vastapaino, 36-54.

Tuori, Kaarlo (2005) Sosiaalioikeus. Helsinki: WSOY.

Ukkonen-Mikkola, Tuulikki (2011) Sukupolvien kohtaamisia lasten ja vanhusten yhteisessä palvelukeskuksessa.Akateeminen väitöskirja. Tampereen yliopisto. Kasvatustieteiden yksikkö.
YK:n ikääntymistä koskevat periaatteet. Madridissa 2002 hyväksytty ikääntymistä koskeva toimintaohje. Sosiaali- ja terveysministeriö.

YK:n lapsen oikeuksien sopimus. Yleissopimus lapsen oikeuksista. 60/1991. 